\title{
Seroprevalence of Hepatitis C and factors associated with this in crack users ${ }^{1}$
}

\author{
Laís Carvalho de Sá2 \\ Telma Maria Evangelista de Araújo ${ }^{3}$ \\ Rosane Harter Griep ${ }^{4}$ \\ Viriato Campelo ${ }^{5}$ \\ Claudete Ferreira de Souza Monteiro ${ }^{3}$
}

Objective: to investigate the seroprevalence of hepatitis C in crack users in Piauí. Method: seroepidemiological survey, undertaken in the Psycho-Social Care Centers for Drugs and Alcohol (CAPS AD) in Piauí in the period December 2011 to May 2012. A questionnaire was administered and blood samples were collected for serological research. Fisher's exact test and the MannWhitney test were used, with a level of significance of $(p<0.05)$. Results: the prevalence of Anti-HCV was $05(1.4 \%)$ and $04(1.1 \%)$ for the RNA-HCV. There was a statistically significant association between hepatitis C (serological marker RNA-HCV) and age, being resident at home, length of use of crack, interruption of the use of crack, and the habit of sharing the crack pipes. Conclusion: the findings support the need to implement health policies aimed at crack users, due to the accelerated process of physical and psychological deterioration to which these are subject.

Descriptors: Hepatitis C; Prevalence; Risk factors; Crack Cocaine.

\footnotetext{
${ }^{1}$ Supported by Conselho Nacional de Desenvolvimento Científico e Tecnológico (CNPq), process \# 402759/2010-9.

2 MSc, RN, Fundação Municipal de Saúde de Teresina, Teresina, PI, Brazil.

${ }^{3} \mathrm{PhD}$, Adjunct Professor, Universidade Federal do Piauí, Teresina, PI, Brazil.

${ }^{4} \mathrm{PhD}$, Researcher, Instituto Oswaldo Cruz, Fundação Oswaldo Cruz, Rio de Janeiro, RJ, Brazil.

${ }^{5} \mathrm{PhD}$, Associate Professor, Universidade Federal do Piauí, Teresina, PI, Brazil.
}

Corresponding Author:

Laís Carvalho de Sá

Rua Senador Esmaragdo de Freitas, 1116

Bairro: Piçarra

CEP: 64017-200, Teresina, PI, Brasil

E-mail: laiscarvalhodesa@hotmail.com
Copyright () 2013 Revista Latino-Americana de Enfermagem This is an Open Access article distributed under the terms of the Creative Commons Attribution Non-Commercial License (CC BY-NC).

This license lets others distribute, remix, tweak, and build upon your work non-commercially, and although their new works must also acknowledge you and be non-commercial, they don't have to license their derivative works on the same terms. 


\section{Introduction}

The viral hepatites are a serious public health problem. Although hepatitis $C$ is universally distributed, its prevalence differs depending on each region's socioeconomic and cultural characteristics. It is interesting to observe that some at-risk populations have higher prevalences when compared to the population in general. In this regard, the consumption of crack related to the hepatitis $\mathrm{C}$ virus ( $\mathrm{HCV}$ ) has begun to awaken the interest of the world scientific community, as the users present risk behaviors which may make them more susceptible to infection.

In dependent use, the crack user faces problems of organic, psychological, social and legal natures. In relation to organic problems, the World Health Organization (WHO) stresses particularly those which are infectious, such as Acquired Immunodeficiency Syndrome (AIDS), hepatitis B and C, and the infective endocardites.

Although hepatitis C's natural history has not been well elucidated, the consensus is that the virus is transmitted by parenteral exposure to blood, transfusion, and medical and dental procedures, and that it may also occur through tattooing and body piercing(1).

The dominant means of transmission of $\mathrm{HCV}$ in the developed countries is the use of injectable drugs, with the sharing of needles being the main risk factor. Nevertheless, infection can also occur as a result of the items used for preparing the drugs. The literature ${ }^{(2-5)}$ refers to the presence of RNA-HCV in body fluids such as saliva, peripheral lymph nodes and semen. It is worth noting that although the virus is found in low titrations, this form of transmission must be considered. Corroborating this understanding of the possibility of other means of transmission, the Center for Disease Control and Prevention (CDC) indicated, in an American health report of 2012 , that $45 \%$ of people with hepatitis $\mathrm{C}$ did not report any known exposure risk ${ }^{(6)}$.

Ratifying this, a study undertaken in Porto Alegre(7) investigated the prevalence of sexually-transmitted diseases (STDs) in female crack users, finding a prevalence of $37 \%$ for Human Immunodeficiency Virus and $27.7 \%$ for HCV. The authors suggest that specific habits may keep these patients at risk of transmission of, and contagion with, infectious-contagious diseases, given that the use of injections had a low frequency in the sample.

In this regard, there are some questions: Is the prevalence of hepatitis $C$ higher among crack users than in the general population? What are the risk factors for hepatitis $\mathrm{C}$ presented by crack users?

In the light of the considerations raised, the disease's seriousness and the scarcity of Brazilian studies associating the use of crack as a risk behavior for acquiring hepatitis $C$, the present study is considered to be relevant, as it will allow the obtaining of local/ regional epidemiological data on infection among crack users, furthering the understanding of the risk factors, as well as serving as support for the establishing of policies and strategies for prevention.

Based on the above, this study aims to investigate hepatitis $C$ seroprevalence and associated factors among crack users in the CAPS AD in Piauí (PI).

\section{Methodology}

This research was undertaken through a seroepidemiological survey and is part of a wider research program entitled "Hepatitis B and C seroprevalence in crack users in the Piauí CAPS AD".

It was carried out in the Brazilian state of Piauí in the Psycho-Social Care Centers - Alcohol and Drugs (CAPS AD) located in four municipalities; Teresina, Parnaíba, Picos and Piripiri. The study's source population was made up of 2,971 crack users registered in the state's four CAPS AD. In the sample calculation, for the total of 353 participants, an acceptable error of $5 \%$ was taken into account, with a level of significance of $95 \%$, and through proportional stratification ${ }^{(8)}$.

The inclusion criteria were to be a crack user registered with the CAPS AD, and to accept to participate in the research. The exclusion criteria were for the user to be unable, at the time of data collection, to respond to the questions of interest to the research, as well as the absence of the express consent of the responsible party, in the case of adolescent crack users.

Data collection was undertaken in the period December 2011 - May 2012, and occurred in four stages, namely:

-Administration of a questionnaire, with closed and semi-open questions, which had been previously tested so as to improve it, to test the performance of the field researchers, and to promote familiarization.

-Observation of the mouth and nose so as to ascertain the presence of blisters and/or lesions.

-Taking of a blood sample so as to research the crack users' serological situation for hepatitis $C$.

-Storage, processing and analysis of the samples. 
The serological markers were researched using the ELISA immunoenzymatic assay described by the Bioeasy ${ }^{\circledR}$ kit. The Bioeasy HCV ELISA Test is an indirect qualitative solid phase immunoenzymatic assay for the detection of the IgG antibody against HCV in human serum or plasma.

The only way of knowing if the infection has passed (spontaneous cure) or is current (acute or chronic) is to carry out tests, by applying the qualitative polymerase chain reaction (PCR), a molecular biology technique, so as to directly detect the viral RNA (RNA-HCV). In this way, in the cases of reagent reactions for the Anti-HCV, the test for the RNA-HCV was undertaken automatically, using the Roche ${ }^{\circledR}$ test.

The data was entered into, and then analyzed using, the Statistical Package for the Social Sciences (SPSS) software, version 19.0. Among the statistical tests, the Mann-Whitney and Fisher tests were applied. The choice of test was based on the verification of the non-normal distribution of the numerical variables. It is important to emphasize that the means presented in the tables of association with the Mann-Whitney test refer to the descriptive analyses of the variables. Statistical significance was fixed at $p \leq 0.05$, with a confidence interval of $95 \%$.

The research project was approved by the Research Ethics Committee (REC) of the Federal University of Piauí (CAAE: 0091.0.45.000-11), and the Terms of Free and Informed Consent (TFIC) were presented to the participants.

\section{Results}

Of the 353 crack users who participated in the study, $183(51.8 \%)$ were aged between 20 and 30 years old, with a mean age of 29.4 , a minimum age of 15 , and a maximum age of 65 . There was a predominance of the male sex, with $297(84.1 \%)$, and in relation to marital situation, 242 (68.6\%) were single/separated. In regard to education, 165 (46.7\%) had not completed junior high school. The mean family income was $R \$ 1,668$, this varying between $R \$ 30$ and $R \$ 20,000$ (data not presented).

In relation to the pattern of crack consumption, (Table 1), the majority of the users had used the drug for a period longer than 37 months, with daily frequency. It was observed that a small majority reported interrupting the use of the substance after beginning treatment in the CAPS AD. The materials used most for ingesting the crack or making the crack pipes were: mesclados (marijuana cigarettes containing rocks of crack) and aluminum cans. A small proportion of the sample use the drug in an injectable form.

Table 1 - Patterns of crack consumption and use of the injectable form of the drug in the study's sample. Teresina, PI, Brazil, $2012(\mathrm{~N}=353)$

\begin{tabular}{|c|c|c|}
\hline Variables & $\mathbf{n}$ & $\%$ \\
\hline \multicolumn{3}{|l|}{ Length of use of crack (months) } \\
\hline Up to 12 & 78 & 22.1 \\
\hline 13 to 24 & 48 & 13.6 \\
\hline 25 to 36 & 42 & 11.9 \\
\hline 37 and more & 185 & 52.4 \\
\hline \multicolumn{3}{|l|}{ Frequency of crack use } \\
\hline Daily & 197 & 55.8 \\
\hline Once a week & 26 & 7.4 \\
\hline Twice or three times a week & 84 & 23.8 \\
\hline 04 to 05 times a week & 33 & 9.3 \\
\hline Others & 13 & 3.7 \\
\hline \multicolumn{3}{|l|}{ Stopped using crack } \\
\hline Yes & 222 & 62.9 \\
\hline No & 131 & 37.1 \\
\hline \multicolumn{3}{|c|}{$\begin{array}{l}\text { Material used in making the crack pipe or ingesting } \\
\text { the crack* }\end{array}$} \\
\hline PVC & 71 & 20.1 \\
\hline Aluminum cans & 191 & 54.1 \\
\hline Glass & 7 & 2.0 \\
\hline Mesclados & 197 & 55.8 \\
\hline Others & 69 & 19.5 \\
\hline \multicolumn{3}{|l|}{ Habit of sharing the pipe } \\
\hline Yes & 255 & 72.2 \\
\hline No & 98 & 27.8 \\
\hline \multicolumn{3}{|l|}{ Use of the drug in injectable form } \\
\hline Yes & 46 & 13.0 \\
\hline No & 307 & 87.0 \\
\hline \multicolumn{3}{|c|}{$\begin{array}{l}\text { Sharing of needles/syringes for use of injectable drugs } \\
\text { in the past }(n=46)\end{array}$} \\
\hline Frequently & 5 & 10.9 \\
\hline Sometimes & 14 & 30.4 \\
\hline Never & 27 & 58.7 \\
\hline
\end{tabular}

*Multiple response

According to Table 2, a significant majority has sexual relations only with women, has a single partner, and uses condoms frequently. A minority reported having contracted a STD. Regarding other predictive factors for $\mathrm{HCV}$ infection, there was a predominance of a history of imprisonment and having a tattoo. A minority had received blood transfusions, had body piercings, and had blisters or lesions in the oral and nasal mucosa.

In the researching of the serological markers for hepatitis C (Table 3), 05 (1.4\%) were positive for Anti$\mathrm{HCV}$ and $04(1.1 \%)$ for the RNA-HCV.

In Table 4, there was a statistically-significant association between RNA-HCV and age $(p=0.02)$, living alone $(p<0.01)$ and greater length of crack use $(p=0.01)$. 
A statistically-significant association was observed between RNA-HCV and continuity of crack use $(p=0.01)$ and the sharing of the crack pipe $(p<0.01)$. The other variables tested did not present statistical association (Table 5).

Table 2 - Predictive factors for infection with the hepatitis C virus in the study's sample. Teresina, PI, Brazil, 2012 $(\mathrm{N}=353)$

\begin{tabular}{|c|c|c|}
\hline Variables & $\mathbf{n}$ & $\%$ \\
\hline \multicolumn{3}{|l|}{ Usually has sexual relations } \\
\hline Only with women & 276 & 78.2 \\
\hline Only with men & 42 & 11.9 \\
\hline With either sex & 34 & 9.6 \\
\hline Has never had sexual relations & 1 & 0.3 \\
\hline \multicolumn{3}{|c|}{$\begin{array}{l}\text { Number of sexual partners in the last } 6 \text { months } \\
(n=301)\end{array}$} \\
\hline One & 143 & 40.5 \\
\hline 2 to 5 & 106 & 30.0 \\
\hline 6 and more & 52 & 14.7 \\
\hline \multicolumn{3}{|c|}{$\begin{array}{l}\text { Has already had relations with a user of injectable } \\
\text { drugs }(n=352)\end{array}$} \\
\hline Yes & 28 & 8.0 \\
\hline No & 324 & 92.0 \\
\hline \multicolumn{3}{|l|}{ Uses Condoms ( $n=352)$} \\
\hline Frequently & 191 & 54.3 \\
\hline Sometimes & 105 & 29.8 \\
\hline Never & 56 & 15.9 \\
\hline \multicolumn{3}{|l|}{ Has already had a STD $(n=352)$} \\
\hline Yes & 110 & 31.2 \\
\hline No & 242 & 68.8 \\
\hline \multicolumn{3}{|l|}{ Has a history of imprisonment } \\
\hline Yes & 236 & 66.9 \\
\hline No & 117 & 33.1 \\
\hline
\end{tabular}

Table 2 - (continuation)

\begin{tabular}{|c|c|c|}
\hline Variables & $\mathbf{n}$ & $\%$ \\
\hline \multicolumn{3}{|c|}{ Length of imprisonment (in days) $(n=236)$} \\
\hline 1 to 7 & 113 & 47.9 \\
\hline 8 to 96 & 56 & 23.7 \\
\hline 120 to 6,935 & 67 & 28.4 \\
\hline \multicolumn{3}{|l|}{ Has already had a blood transfusion } \\
\hline Yes & 31 & 8.8 \\
\hline No & 322 & 91.2 \\
\hline \multicolumn{3}{|l|}{ Year of blood transfusion $(n=31)$} \\
\hline 1971 to 1993 & 5 & 16.1 \\
\hline 1994 to 2012 & 26 & 83.9 \\
\hline \multicolumn{3}{|l|}{ Has a tattoo } \\
\hline Yes & 209 & 59.2 \\
\hline No & 144 & 40.8 \\
\hline \multicolumn{3}{|l|}{ Use of piercing } \\
\hline Yes & 40 & 11.3 \\
\hline No & 313 & 88.7 \\
\hline \multicolumn{3}{|l|}{ Blister or lesion in the oral mucosa } \\
\hline Yes & 43 & 12.2 \\
\hline No & 310 & 87.8 \\
\hline \multicolumn{3}{|l|}{ Lesion in the nasal mucosa } \\
\hline Yes & 18 & 5.1 \\
\hline No & 335 & 94.9 \\
\hline
\end{tabular}

Table 3 - Distribution of the prevalence of serological markers of hepatitis $\mathrm{C}$ in the study's sample. Teresina, PI, Brazil, $2012(\mathrm{~N}=353)$

\begin{tabular}{lccc}
\hline & Variables & $\mathbf{n}$ & $\%$ \\
\hline Anti-HCV & & \\
Reagent & 5 & 1.4 \\
Non-reagent & 348 & 98.6 \\
RNA-HCV & & \\
Reagent & 4 & 1.1 \\
Non-reagent & 349 & 98.9 \\
\hline
\end{tabular}

Table 4 - Association between RNA-HCV and the variables: mean age, resident at home, family income, months of crack use, number of partners in the previous six months and length of time spent imprisoned. Teresina, PI, Brazil, $2012(\mathrm{~N}=353)$

\begin{tabular}{|c|c|c|c|c|}
\hline RNA-HCV & $\mathbf{n}$ & Mean & Standard Deviation & p value* \\
\hline Age & & & & 0.02 \\
\hline Reagent & 4 & 40.2 & 8.2 & \\
\hline Non-reagent & 349 & 29.3 & 8.7 & \\
\hline Resident at home & & & & $<0.01$ \\
\hline Reagent & 4 & 1.0 & & \\
\hline Non-reagent & 349 & 4.1 & 2.2 & \\
\hline Family income (in Brazilian reais) & & & & 0.43 \\
\hline Reagent & 4 & 916.5 & 589.0 & \\
\hline Non-reagent & 327 & 1677.6 & 1999.6 & \\
\hline Months of crack use & & & & 0.01 \\
\hline Reagent & 4 & 132.0 & 73.9 & \\
\hline Non-reagent & 349 & 55.5 & 50.2 & \\
\hline
\end{tabular}


Table 4 - (continuation)

\begin{tabular}{|c|c|c|c|c|}
\hline RNA-HCV & $\mathbf{n}$ & Mean & Standard Deviation & p value* \\
\hline Number of partners in the previous six months & & & & 0.53 \\
\hline Reagent & 4 & 7.0 & 7.6 & \\
\hline Non-reagent & 349 & 3.3 & 6.4 & \\
\hline Days imprisoned & & & & 0.15 \\
\hline Reagent & 4 & 274.0 & 182.0 & \\
\hline Non-reagent & 230 & 215.9 & 715.2 & \\
\hline
\end{tabular}

${ }^{*} p$ value was obtained through the Mann-Whitney test. The statistical significance was fixed at $p \leq 0.05$

Table 5 - Association between RNA-HCV and the variables: interruption of the use of crack, sharing of the crack pipe, injectable drug, STD, imprisonment, tattooing, body piercing, blisters and lesions in the oral mucosa, and lesions in the nasal mucosa. Teresina, PI, Brazil, $2012(\mathrm{~N}=353)$

\begin{tabular}{|c|c|c|c|}
\hline \multirow{3}{*}{ Variables } & \multicolumn{2}{|c|}{ RNA-HCV } & \multirow{3}{*}{ p value } \\
\hline & Reagent & Non-reagent & \\
\hline & n (\%) & n (\%) & \\
\hline Interruption in the use of crack & & & 0.01 \\
\hline Yes & - & $222(100.0)$ & \\
\hline No & $04(3.8)$ & $127(96.9)$ & \\
\hline Habit of sharing the crack pipe & & & $<0.01$ \\
\hline Yes & - & $251(98.4)$ & \\
\hline No & $04(1.6)$ & $93(94.9)$ & \\
\hline Use of injectable drug & & & 0.57 \\
\hline Yes & - & $46(100.0)$ & \\
\hline No & $04(1.3)$ & $303(98.7)$ & \\
\hline Has previously had STD & & & 0.22 \\
\hline Yes & - & $110(100.0)$ & \\
\hline No & $04(1.6)$ & $239(98.4)$ & \\
\hline Has been imprisoned & & & 0.19 \\
\hline Yes & $04(1.7)$ & $232(98.3)$ & \\
\hline No & - & $117(100.0)$ & \\
\hline Has a tattoo & & & 0.12 \\
\hline Yes & $04(1.9)$ & $205(98.1)$ & \\
\hline No & - & $144(100.0)$ & \\
\hline Has body piercing & & & 0.61 \\
\hline Yes & - & $40(100.0)$ & \\
\hline No & $04(1.3)$ & $309(98.7)$ & \\
\hline Blisters or lesion in oral mucosa & & & 0.59 \\
\hline Yes & - & $43(100.0)$ & \\
\hline No & $04(1.3)$ & $306(98.7)$ & \\
\hline Lesion in nasal mucosa & & & 0.81 \\
\hline Yes & - & $18(100.0)$ & \\
\hline No & $04(1.2)$ & $331(98.8)$ & \\
\hline
\end{tabular}

${ }^{*} p$ value was obtained with Fisher's exact test. Statistical significance was fixed at $p \leq 0.05$

\section{Discussion}

The socio-demographic characterization of the sample produced a result similar to that ascertained in the first investigation on crack consumption, carried out in São Paulo in 1994(9), which confirmed a preponderance of men, younger than 30 years old, unemployed, with little education, and from dysfunctional families.

Regarding the characteristics related to the pattern of crack consumption, the observed was increasingly heavy consumption at progressively shorter intervals, explaining the fact that $37.1 \%$ of the crack users used the drug even while being treated in the Piauí CAPS AD. The tendency for increase in the need for crack was also ascertained in a study ${ }^{(10)}$ undertaken with drug users in the city of Rio de Janeiro in the period 2007-2008.

In order to smoke a rock of crack, the crack users use a type of pipe, and structures improvised from tin cans, plastic or cardboard tubes, aluminum foil, hydraulic parts, and even the wrappers from foodstuffs ${ }^{(11)}$. In relation to 
the materials used for making artifacts for ingesting the crack, among the users in the present study, a preference for smoking mesclados was observed, followed by beer and soft drink cans. The 'mesclado', a marijuana cigarette with crack rocks mixed in with the marijuana, is a less harmful means of ingestion, as it reduces the fissuring, and other, anxiogenic, effects of $\operatorname{crack}^{(11)}$.

When they lack materials for making pipes, the users consume the drug in aluminum cans which they often find in the trash. In Brazil, this form of use has been well documented. In addition to the risk of the presence of infectious agents in these cans found in the gutter or trash, it should be emphasized that the high level of aluminum in brain tissue causes changes in cognitive and neurological function ${ }^{(12)}$.

It is common for crack users to share pipes between themselves, a behavior verified by the majority of this study's population. In this way, those who smoke crack have possibilities for infectious contamination ${ }^{(1,5)}$.

In relation to the consumption of injectable drugs, it was observed that this means was abandoned, possibly due to the perception of risk involving this practice and contagion with HIV, the infectious illness which causes the most commotion worldwide. In spite of the reduction in Injection Drug Users (IDUs), it is estimated that 10 million people who inject drugs were infected with HCV in 2011(1).

At the time of writing, the role of sexual behaviors in the transmission of $\mathrm{HCV}$ remains controversial. However, several authors have asserted some risk factors for acquiring $\mathrm{HCV}$, including biological factors (being HIV-positive and having other sexually-transmissible infections), rough sexual practices (anal sex, use of sex toys), and having multiple sexual partners(13). In relation to crack, it has been evidenced in studies that less safe sexual practices are frequently associated with this substance, examples being a large number of sexual partners, unprotected sex, and sex in exchange for drugs or money.

The non-use of condoms was reported by part of the population studied. A higher frequency was found by researchers in a separate study ${ }^{(14)}$, in which $49.3 \%$ of crack users reported that they rarely used them, in spite of their being available for free in the health services.

Due to the irregular use of condoms, the finding that there was a $31.2 \%$ incidence of STDs in the present research is understandable. The use of psycho-active substances can make drug addicts less aware of or concerned about STDs(15). In one randomized study, the prevalence of HCV antibodies was significantly $(p \leq 0.001)$ higher in the group of heterosexuals infected with STDs than in the control group (without STDs); $5.3 \%$ compared to $0.5 \%{ }^{(16)}$. One possible explanation is that as some sexually-transmissible infections are ulcerative, the presence of ulcers as a gateway may have facilitated the contamination of the organism by HCV.

In relation to the problems which involve the Police or justice system, the study ascertained that a significant majority of crack users have previously had an episode of imprisonment. This data is worrying given that the rates of prevalence of $\mathrm{HCV}$ in prisons and other closed institutions are higher than in the community. This occurs due to the limited access to materials, and risk practices that are undertaken, such as tattooing or body piercing without sterilized instruments, homosexual sexual practices, sexual attacks, and the sharing of injectable and non-injectable drug paraphernalia. In one study ${ }^{(17)}$ undertaken in South America, in HCV monoinfected persons were significantly more likely to have been imprisoned.

In the sample studied, $8.8 \%$ had received blood transfusions. Following the introduction in 1993 of Anti-HCV testing in the routine of health surveillance, particularly in the bloodbanks, the rates of posttransfusion hepatites have fallen increasingly lower, making transfusions and transplants rare means of transmission. However, there is still a risk of there being cases of post-transfusional hepatites as a result of the immunological window ${ }^{(6)}$.

There was a predominance of tattooed crack users, but only a small proportion had body piercing. Although people with multiple tattoos and/or perforations have an increased risk of HCV due to the absence of sterilization processes, this association has been irregular among the studies.

It is important to note that some cases approximately $15 \%$ - of hepatitis C are of unknown origin in the general population. One hypothesis which may explain infections with HCV among users of noninjectable drugs was proposed by researchers of the National Institutes of Health)(NIH) in the USA(18), who identified crack use as a risk factor for HCV among blood donors. They argued that the virus can be transmitted by means of contaminated instruments.

This transmission occurs due to the existence of burns and blisters on the fingertips, mouth and nose, as a result of the heating-up of the pipes. The blood from the oral and nasal lesions can be transferred via the paraphernalia for consuming crack to the ulcerated mucosa of another user ${ }^{(17)}$. 
There are innumerable studies on the presence of RNA-HCV in the saliva ${ }^{(2-5)}$ but their results vary, reflecting the heterogeneity of the populations studied, and the variety of detection techniques used. Nevertheless, epidemiological studies suggest that the infectious capacity of viral particles of HCV in the saliva is low. There is no evidence that HCV is easily transmitted by kissing, sneezing, coughing or sharing cups and plates ${ }^{(19)}$.

In spite of the presence of blisters or lesions in the oral and nasal mucosa in a proportion of the sample, the prevalence found was of $1.4 \%$ for the Anti-HCV and $1.1 \%$ for RNA-HCV. The prevalence of hepatitis C among the crack users was similar to that estimated for Brazil with $1 \%$ to $2 \%$, as well as for the chronic cases of hepatitis $C$ which represent $1.5 \%$ of the population ${ }^{(20)}$.

In relation to the Brazilian panorama, it is important to stress that there is a shortage of information on $\mathrm{HCV}$ among crack users. The result was below that found among crack users in Bahía, with $2.4 \%^{(14)}$ and similar to that among adults in Criciúma, with $1.53 \%{ }^{(21)}$.

Comparing the prevalence rates around the world, prevalences were observed which are higher than that calculated in the population studied. One study(17) estimated the prevalence of $\mathrm{HCV}$ in Buenos Aires (Argentina) and Montevideo (Uruguay) at $8.8 \%$. In Mexico, the prevalence of hepatitis $\mathrm{C}$ among the users of non-injectable drugs was $4.1 \%{ }^{(22)}$. Nevertheless, it was lower than that found in Canada $(0.8 \%)^{(23)}$.

Regarding the association of hepatitis $C$ with age, this finding was in accordance with other investigations of users of illicit drugs ${ }^{(10)}$. A longer period of crack use was statistically associated with RNA-HCV. This occurs due to the cumulative effect of exposure to the risk of infection by HCV.

In relation to the number of people who live at home, it was ascertained that crack users who are positive for hepatitis $C$ lived alone. The Brazilian Association of Psychiatry(24) states that positive relationships in the family environment are always protective and provide structure, reducing the individuals' vulnerability for drug consumption. The norms for social behaviors, including risk practices, are developed in the relationships with the primary sources of socialization: the family, the school, and the friends in adolescence.

Regarding the continued use of crack, it was evidenced that the fact that the users had not stopped consuming the substance, even when in treatment, suggests a greater association with hepatitis $C$, due to the risk behaviors described above.

No association was found between the sharing of equipment and HCV seroprevalence among noninjectable drug users, in spite of the literature(25) indicating that sharing crack-smoking equipment is statistically-associated with HCV.

\section{Conclusion}

Regarding serological condition, $1.4 \%$ were positive for Anti-HCV and $1.1 \%$ for RNA-HCV. In this way, in spite of the risk behaviors (abusive consumption of crack, sharing crack pipes, non-use of condoms, episodes of imprisonment and being tattooed), the prevalence of hepatitis $C$ found for the crack users was similar to the estimate found for the Brazilian population in general, and below the worldwide estimate. The following variables were statistically associated with RNA-HCV: age, length of use of crack, living at home, cessation of crack use, and the habit of not sharing the crack pipes.

It was ascertained that the repeated use of the heated-up crack pipe can cause blisters and wounds, on the tongue, lips, face, nostrils and fingers. However, in this study it was not possible to affirm the hypothesis of the transmission of the virus through the sharing of the paraphernalia used in crack consumption.

This study leads to the reflection that, as hepatitis C normally follows an indolent course, the identification of risk factors for infection is essential for the development of effective early intervention strategies. It is relevant to set up health education programs directed at crack users concerning risk behaviors which expose them to infectious diseases, such as hepatitis $C$, due to the accelerated process of physical and psychological deterioration to which they are subject.

The results of low prevalence of, and non-association of, hepatitis $C$ with the presence of blisters and lesions in the oral and nasal mucosa may be attributed to the study's limitations. Information bias may have occurred, given that the responses were self-declared. The presence of false negatives, occasionally, is a problem. The lack of a control group, the cross-sectional design and relatively small sample may have made the analysis of the results difficult. For this reason, further research is necessary so as to deepen knowledge of the issue.

\section{References}

1. Nelson PK, Mathers BM, Cowie B, Hagan $H$, Jarlais DD, Horyniak D, et al. Global epidemiology of hepatitis $B$ and hepatitis $C$ in people who inject drugs: results of systematic reviews. Lancet. 2011; 378(9791):571-83. 
2. Pekler VA, Robbins WA, Nyamathi $A$, Yashina $T L$, Leak

$B$, Robins TA. Use of versant TMA and bDNA 3.0 assays to detect and quantify hepatitis $C$ virus in semen. J Clin Lab. 2003;17(6):264-70.

3. Ferreiro MC, Dios PD, Scully C. Transmission of hepatitis C virus by saliva? Oral Dis. 2005;11(4):230-5. 4. Suzuki T, Omata K, Satoh T, Miyasaka T, Arai C, Maeda $M$, et al. Quantitative detection of hepatitis $C$ virus (HCV) RNA in saliva and gingival crevicular fluid of HCV-infected patients. J Clin Microbiol. 2005;43(9):4413-7.

5. Menezes GBL, Pereira FA, Duarte CAB, Carmo TMA, Silva HP Filho, Zarife MA, et al. Hepatitis $C$ virus quantification in serum and saliva of $\mathrm{HCV}$-infected patients. Mem Inst Oswaldo Cruz. 2012;107(5):680-3.

6. Centers for Disease Control and Prevention (USA). Recommendations for the Identification of Chronic Hepatitis C Virus Infection Among Persons Born During 1945-1965. MMWR Recomm Rep. 2012 Aug;61(RR-4):1-32. Erratum in: MMWR Recomm Rep. 2012 Nov 2;61(43):886.

7. Von Diemen L, De Boni R, Kessler F, Benzano D, Pechansky F. Risk behaviors for HCV- and HIVseroprevalence among female crack users in Porto Alegre, Brazil. Arch Womens Ment Health. 2010;13(3):185-91.

8. Callegari-jacques S. Bioestatística: princípios e aplicações. Porto Alegre: Artmed; 2003.

9. Nappo AS, Galduróz JCF, Noto AR. Uso do "crack" em São Paulo: fenômeno emergente? Rev ABP-APAL. 1994;16(2):75-83.

10. Vargens RW, Cruz MS, Santos MA. Comparison between crack and other drugs abusers in a specialized outpatient facility of a university hospital. Rev. LatinoAm. Enfermagem. 2011;19(spe):804-12.

11. Oliveira LG, Nappo SA. Crack na cidade de São Paulo: acessibilidade, estratégias de mercado e formas de uso. Rev Psiquiatr Clín. 2008;35(6):212-8.

12. Pechansky F, Kessler FHP, Von Diemen L, Bumaguin $D B$, Surratt $H L$, Inciardi JA. Brazilian female crack users show elevated serum aluminum levels. Rev Bras Psiquiatr. 2007;29(1):39-42.

13. Stall R, Wei C, Raymond HF, McFarland W. Do rates of unprotected anal intercourse among HIV-positive MSM present a risk for hepatitis $C$ transmission? Sex Transm Infect. 2011;87(5)439-41.

14. Nunes CLX, Andrade T, Galvão-Castro B, Bastos FI, Reingold $A$. Assessing risk behaviors and prevalence of sexually transmitted and blood-borne infections among female crack cocaine users in Salvador-Bahia, Brazil. Braz. J Infect Dis. 2007;11(6):561-6.
15. Bradshaw CS, Pierce LI, Tabrizi SN, Fairley CK, Garland SM. Screening injecting drug users for sexually transmitted infections and blood borne viruses using street outreach and self collected sampling. Sex Transm Infect. 2005;81(spe):53-8.

16. Petersen EE, Clemens R, Bock HL, Friese $K$, Hess

G. Hepatitis $B$ and $C$ in heterosexual patients with various sexually transmitted diseases. Infection. $1992 ; 20(3): 128-31$.

17. Caiaffa $\mathrm{WT}$, Zocratto KF, Osimani ML, Martínez $\mathrm{PL}$, Radulich $G$, Latorre $L$, et al. Hepatitis $C$ virus among noninjecting cocaine users (NICUs) in South America: can injectors be a bridge? Addiction. 2011;106(1):143-51.

18. Conry-Cantilena C, Van Raden M, Gibble J, Melpolder J, Shakil AO, Viladomiu L, et al. Routes of infection, viremia, and liver disease in blood donors found to have hepatitis $C$ virus infection. N Engl J Med. 1996;334(26):1691-6.

19. Zeremski M, Makeyeva J, Arasteh K, Des Jarlais DC, Talal $\mathrm{AH}$. Hepatitis $\mathrm{C}$ virus-specific immune responses in noninjecting drug users. J Viral Hepat. 2012;9(8):554-9. 20. Ministério da Saúde (BR). Programa Nacional de Prevenção e Controle da Hepatite Viral. Manual de aconselhamento em hepatites virais. Brasília; 2005.

21. Fagundes GD, Bonazza V, Ceretta LB, Back AJ, Betiol J. Detection of the hepatitis $c$ virus in a population of adults. Rev. Latino-Am. Enfermagem. 2008;16(3):396400.

22. Campollo O, Roman S, Panduro A, Hernandez G, Diaz-Barriga L, Balanzario $M C$, et al. Non-injection drug use and hepatitis $C$ among drug treatment clients in west central Mexico. Drug Alcohol Dependence. 2012;123(13):269-72.

23. Public Health Agency of Canada. Evaluation of the hepatitis $C$ prevention, support and research program 1999/2000-2005/2006. [Internet]. [acesso 13 out 2012].Canadá; 2009. Disponível em: http:// www.phacaspc.gc.ca/publicat/2008/er-re-hepc/er-re-hepc1-eng. php\#ref..

24. Associação Brasileira de Psiquiatria. Conselho federal de Medicina. Diretrizes para um modelo de assistência integral em saúde mental no Brasil. Brasília; 2006. 58 p. 25. Macías J, Palacios RB, Claro E, Vargas J, Vergara $S$, Mira JA, et al. High prevalence of hepatites $C$ virus infection among noninjecting drug users: association with sharing the inhalation implements of crack. Liver Int. $2008 ; 28(6): 781-6$. 